\title{
Norwegian art and crafts teachers' conceptions of creativity
}

\author{
Brynjar Olafsson* \\ University of South-Eastern Norway
}

\begin{abstract}
This study investigates Norwegian art and crafts teachers' conceptions of creativity through the responses to a questionnaire from 791 teachers in compulsory education. The curriculum in Norway for compulsory education emphasizes the development of creativity in the art and crafts field more than in the other core subjects. However, the curriculum does not offer a clear definition of creativity or how creativity-related goals should be reached. According to prior research, teachers express different ideas about what creativity involves, and their conceptual understanding can affect their teaching practices. Results indicate that teachers hold beliefs that are in misalignment with recent literature, and a better conceptual understanding could support them in emphasizing creativity in the classroom. This applies especially to individual creative capacity, assessment, and the role played by domain knowledge in education.
\end{abstract}

Keywords: Art and crafts education; compulsory education; Norway; creativity

Received: May, 2019; Accepted: November, 2019; Published: February, 2020

\section{Introduction}

Creativity is recognized as a fundamental skill that is indispensable in a complex and ever-changing digital age (Craft, 2011). For this reason, the issue of creativity is receiving increased attention within compulsory education in many countries (Beghetto \& Kaufman, 2017). According to a recent Norwegian study, leaders of innovative production companies often identify creativity and experience as more important than formal education when seeking new employees (Svare, 2014). Despite creativity being highlighted in the national curriculum (Ministry of Education and Research, 2006), Gjærum and Gran (2016) posit that the Norwegian compulsory education system tends to depress creativity and demotivate students with significant emphasis on theoretical subjects. Others have stressed that creativity is in crisis and that creative thinking has decreased (Kim, 2011). Many creativity scholars have suggested

\footnotetext{
${ }^{\star}$ Correspondence: Brynjar Olafsson. E-mail: brynjar.olafsson@usn.no
} 
ways to support student creativity in all school subjects (e.g., Beghetto, 2013; Craft, 2000; Renzulli, 2017). Gjærum and Gran (2016), however, point to art and crafts as well suited for supporting creativity skills in compulsory education.

Art and crafts (A\&C) as a school subject has indeed often been viewed as a suitable platform for practicing creativity. Previous research indicates that teachers in Norway consider $\mathrm{A} \& \mathrm{C}$ as important for student's general development, creativity, and for improving academic results in other subjects (Espeland et al., 2013). Therefore, it is no coincidence that concepts related to creativity appear 16 times in the national compulsory $\mathrm{A} \& \mathrm{C}$ curriculum, but only six times in the curriculum for Norwegian, and twice in the natural sciences curriculum in comparison. Consequently, the A\&C curriculum aims to provide students with opportunities to practice their creativity using a range of different materials and through utilizing various techniques and tools (Ministry of Education and Research, 2006).

Nevertheless, this does not mean that A\&C students actually receive more opportunities to be creative. The report, Art for Art's Sake, on the impact of arts education in the OECD countries, states that "[d] espite the common assumption that arts education teaches creativity, we found little evidence for this hypothesis in the area of multiarts and visual arts education" (Winner, Goldstein \& Vincent-Lancrin, 2003, p. 185). This could be linked to the fact that teachers find it difficult to translate positive attitudes regarding creativity to creativity-fostering practices (Bereczki \& Karpati, 2018; Eckhoff, 2011). According to Craft (2000), fostering creativity requires a commitment to fostering the physical space in which creativity occurs as well as a clear conceptual understanding. When reviewing recent research literature on creative learning environments, Davies et al. (2013) concluded that teachers have different ideas regarding the concept of creativity, and this can be an obstacle when attempting to teach creativity (see also Bereczki \& Karpati, 2018; Diakidoy \& Kanari, 1998). With clear conceptual knowledge, teachers will know better when or how to encourage creative experimentation and risk-taking, or how to respond to students' mistakes, questions, and actions.

Given the strong link the A\&C school subject has to creativity, it appears that A\&C teachers have greater responsibility to develop creativity skills in students. This study, therefore, sets out to investigate how Norwegian A\&C teachers within compulsory education understand creativity. Some previous research studies have included A\&C teachers without identifying explicitly their conceptions. The question asked in this article is: How do AEC teachers in Norwegian compulsory education comprehend creativity?

\section{Art and crafts in compulsory education in Norway}

The current Norwegian compulsory curriculum, Kunnskapsløftet (i.e., the Knowledge Promotion Reform), aims to help students overcome life challenges, prepare for undiscovered professions, master changing environments, and confidently face a constantly evolving future (Ministry of Education and Research, 2006). The development of creativity in individuals is thus, both explicitly and implicitly, one of the 
most important aspects of compulsory education. For this reason, its relevance is emphasized in a number of different subject areas.

The national curriculum underlines the importance of developing creativity through $\mathrm{A} \& \mathrm{C}$ education. Moreover, it considers knowledge acquired through $\mathrm{A} \& \mathrm{C}$ to be an important basis for "... personal development that is a premise for purposeful creative idea generation, visual communication and production" (Ministry of Education and Research, 2006). Furthermore, it underlines the importance of developing aesthetic competence within a creative context to help students influence their environment and society.

The $\mathrm{A} \& \mathrm{C}$ curriculum is divided into four main areas: visual communication, design, art, and architecture. Creativity is emphasized in all these areas. Competence aims are formulated for each area by the end of Grades 2, 4, 7, and 10. Five fundamental skills form the basis of the four main areas. Accordingly, the students should be able to:

- express themselves verbally; communicating with others and presenting their own work,

- express themselves in writing; using both visual and symbolic expressions,

- read; interpreting signs and symbols and finding inspiration in the creative work of others,

- calculate; working with proportions, dimensions, and geometric drawings, and

- use digital tools; finding information and producing digital drawings.

(Ministry of Education and Research, 2006, p. 93)

More than in the past, the current A\&C curriculum emphasises creativity, problemsolving skills through craft and design, and artistic activities based on students' experiences. These creative activities enhance the students' understanding of their environment, their abilities to express themselves and to communicate.

The students learn to work with different materials and to develop their own ideas through problem solving. The students' experiences are linked to art, design, and architecture, which relate their practical work to a social context. Creativity in the $\mathrm{A} \& \mathrm{C}$ curriculum is regarded as important for students' general development and their abilities to influence their environment (society). The A\&C curriculum, furthermore, encourages students to participate in entrepreneurial activities, focusing on the development of skills or attributes that enable the realisation of a creative idea.

According to these aforementioned elements, the intention of the $A \& C$ curriculum is to have creativity as a well-integrated part of teaching and learning.

\section{Creativity and learning}

Creativity is defined in this paper as the invention of something that is both novel and task-appropriate (Helfand, Kaufman, \& Beghetto, 2017; NACCCE, 1999; Runco \& Jaeger, 2012). Creativity is a key component in human cognition, and many scholars 


\section{B. Olafsson}

have pointed out that there is a strong relationship between creativity and learning (Beghetto \& Kaufman, 2007; Sawyer, 2010; Vygotsky, 1967/2004). Vygotsky (1967/2004) states that creativity is the combinatorial process of the imagination. He says that when an individual acquires new knowledge, it does not transmit passively, but is internalized through verbal communication, observation, and participation. By transforming and connecting information with prior knowledge and experience, the receiver creates a unique understanding (Moran \& John-Steiner, 2003). This transformative internalization can in itself be creative, and the unique individual understanding can be a part of later objective creative expressions (Beghetto \& Kaufman, 2007). Consequently, all healthy individuals who are able to learn should have the capacity to be creative.

This personal understanding is subjective. However, in education the focus is usually on objective products within a school subject or domain. Little dispute exists among creativity scholars that extensive domain knowledge is important to make a valuable contribution to a domain and reach the status of eminent creators (Csikszentmihalyi, 1998; Gardner, 1993; Sawyer, 2012). However, debate continues on whether creativity is best viewed as domain-general or domain-specific in the context of education (e.g., Baer, 2019; Plucker \& Beghetto, 2004). Creativity can be viewed as domain-general because it can be defined as an attitude toward life, and people can develop a creative mindset that can potentially be used across domains (Olafsson \& Gulliksen, 2018; Sternberg, 2009). The main argument for domain-specificity, on the other hand, is that creativity is not something that can be taught without context but must be taught domain by domain (Baer, 2019). According to Plucker and Beghetto (2004), one way of looking at this dichotomy is to focus on transfer of skills and knowledge to new situations. Plucker and Beghetto (2004) argue that transfer can be hindered with too much specificity or too much generality; they propose balance and flexibility between the two in education. However, recent research literature on transfer indicates that deep understanding of essential knowledge and skills in a subject matter will support transfer (Pellegrino \& Hilton, 2013; Sawyer, 2014). Knowledge that extends beyond the surface memorization, and is authentic to reallife work experience, will be easier for students to apply in new and meaningful ways (National Research Council, 2000; Sawyer, 2010). Consequently, focusing on deep knowledge in school subjects will increase transfer and thereby creativity, because creativity is all about making new and novel connections within and across domains.

To support the creativity of students, teachers must be able to assess the process (Beghetto, 2010, 2013). Assessment is also a challenge when it comes to A\&C (Lutnæs, 2013), and attempts have been made in Norway to design tools to assess creativity (e.g., Lutnæs, 2009; Lutnæs 2018; Moe, 2012; Øidvin, 2010). Lutnæes (2011) interviewed seven Grade 10 A\&C teachers within compulsory education in Norway and found that they focused mostly upon mastering technical skills together with original and personal expression. The respondents had a clear conception of how to describe the quality of the technical skills, but struggled to verbalize the original or 
personal aspects. Another indication of the complexity of assessment in $A \& C$ is that there are more complaints about the final grade in $A \& C$ than in other school subjects (Skolt, 2014). In a study on the quality, practice, and possibilities in A\&C education in Norway, Bamford (2012) concluded that criteria and directions on assessment are insufficient and need to be developed further.

One of the most widely documented assessment techniques for creativity is the consensual assessment technique developed by Amabile (1982; 1996), in which groups of expert judges assess the actual creative performance. Self-grading measures have also been developed in which individuals rate their own abilities, but according to Hennessey (2017) a comprehensive model that captures the complexity of creativity is yet to be developed.

\section{Teachers' conceptions of what creativity is}

According to Pajares (1992), teachers' conceptions about creativity may influence their understanding, teaching practices, and evaluations. A conception is defined in this article as an idea of what something or someone is like, or a basic understanding of a situation or a principle (Colman, 2008). A conception, therefore, does not have to be evidence-based, but can be opinions or beliefs held by an individual.

Bereczki \& Kárpáti (2018) reviewed recent research on teachers' beliefs about creativity and found that several studies reveal inconsistencies between teachers' conceptions and their pedagogical practices; as a result, this can affect children's learning and development. Furthermore, they found that even though teachers are positive and knowledgeable about creativity, many find it difficult to convert their ideas into effective practices. Many teachers, additionally, identify non-creative fostering classroom activities as creative and cannot distinguish between the two (e.g., Al-Nouh, Abdul-Kareem \& Taqi, 2014; Newton \& Newton, 2012; Zbainos \& Anastasopoulou, 2012).

Teachers' basic conceptions of creativity are similar in different parts of the world (Newton \& Beverton, 2012). Teachers tend to support the idea that creativity can be nurtured and used in all domains. The majority, furthermore, connect creativity with originality, independence, and the arts (Davies et al., 2013; Fryer \& Collings, 1991). These ideas are indeed linked to creativity but are in misalignment with current literature and research. Most creativity scholars, for instance, do not link the arts more strongly with creativity than other domains and include task-appropriateness in addition to originality in the basic definition. Studies have also demonstrated that teachers have highly dissimilar views on many aspects of creativity (Cachia \& Ferrari, 2010).

Teachers use ideas intentionally or unintentionally when aiming to support the creativity of children. One of the problems with using ideas unintentionally is that what counts as creative can be different for different school subjects, and the teacher must recognize what represents creativity within his or her subject (Newton, 2012). Teachers in different school subjects may also have various opinions on what represents and constrains creativity. However, little research is available on teachers' conceptions of 
creativity in different school subjects and how their understanding influences their teaching.

\section{Method}

The aim of this research was to explore Norwegian A\&C teacher's conceptions on creativity in Norwegian compulsory education. The research utilized an anonymous, online survey that focused upon various aspects of creativity within the context of $\mathrm{A} \& \mathrm{C}$ compulsory education classes. The author prepared the survey with reference to the Four C model of creativity (see Kaufman \& Beghetto, 2009), two other surveys (Cachia \& Ferrari, 2010; Oskarsdottir et al., 2014), and other recent literature (Amabile, 1996; Baer, 2012; Craft, 2011). An initial survey was discussed with experts in the field before being piloted by 29 A\&C teachers. Following this, some amendments were made, mostly to the wording, to increase the likelihood of a similar understanding of the questions and statements by all the respondents. However, given that previous research has demonstrated different understandings of the concept of creativity (see Bolden, Harries, \& Newton, 2010; Lev-Zamir \& Leikin, 2011; Mullet, Willerson, Lamb \& Kettler, 2016), the respondents' understanding of the questions was expected to differ to some extent.

Emphasized in this article, is how respondents answered 22 closed-end statements that are divided into nine themes (see Appendix 1, a matrix where statements are categorized by themes). A 5-point Likert scale was used to rate the responses.

\section{Administration}

The survey was set up in ProQuest, an online tool for collecting research data. As there is no exclusive register for $\mathrm{A} \& \mathrm{C}$ teachers in compulsory schools in Norway; the size of the population is unknown. Consequently, it was not possible to conduct a random sampling for a study that explicitly targeted that group of teachers. Therefore, in the spring of 2017, the link to a survey intended for A\&C teachers was e-mailed to all 2,872 compulsory schools in Norway (based on a list from the Norwegian Directorate for Education and Training, www.udir.no). The schools' public e-mail addresses were used, and the recipient was asked to forward the survey link to all A\&C teachers within the school. The survey received 791 responses. The response rate is not identifiable due to the unknown population size. Consequently, the results are not optimal because the only teachers who answered were those interested in responding. It is, however, unclear how much this has affected the results. Despite this limitation, the results provide useful intimations about $A \& C$ teachers' perception of creativity.

\section{Respondents}

In the current paper, an $\mathrm{A} \& \mathrm{C}$ teacher is defined as someone who teaches at least two classes in A\&C. This definition excludes those class teachers who are responsible for teaching most subjects to their own class including that of A\&C. A similar 
definition was used in an earlier research project in which the author had participated (Oskarsdottir et al., 2014).

In total, $85.8 \%$ of the respondents were women, eight respondents were under 25 years of age, and the largest age group was $40-49$ years, as depicted in Figure 1.

Of the respondents, $41.3 \%$ had a general teacher education (allmennlarerutdanning), $36.8 \%$ had a specialist teacher education (faglererutdanning), and $16.8 \%$ had completed a one-year program in educational theory and practice (praktiskpedagogisk utdanning) in addition to a bachelor's degree in a subject linked to A\&C. Moreover, $15.7 \%$ had no formal education in $\mathrm{A} \& \mathrm{C}$, and the largest group, consisting of $29.2 \%$, had $90-120$ ECTS credits for formal education in art and crafts (European Credit Transfer System credits) as demonstrated in Table 1.

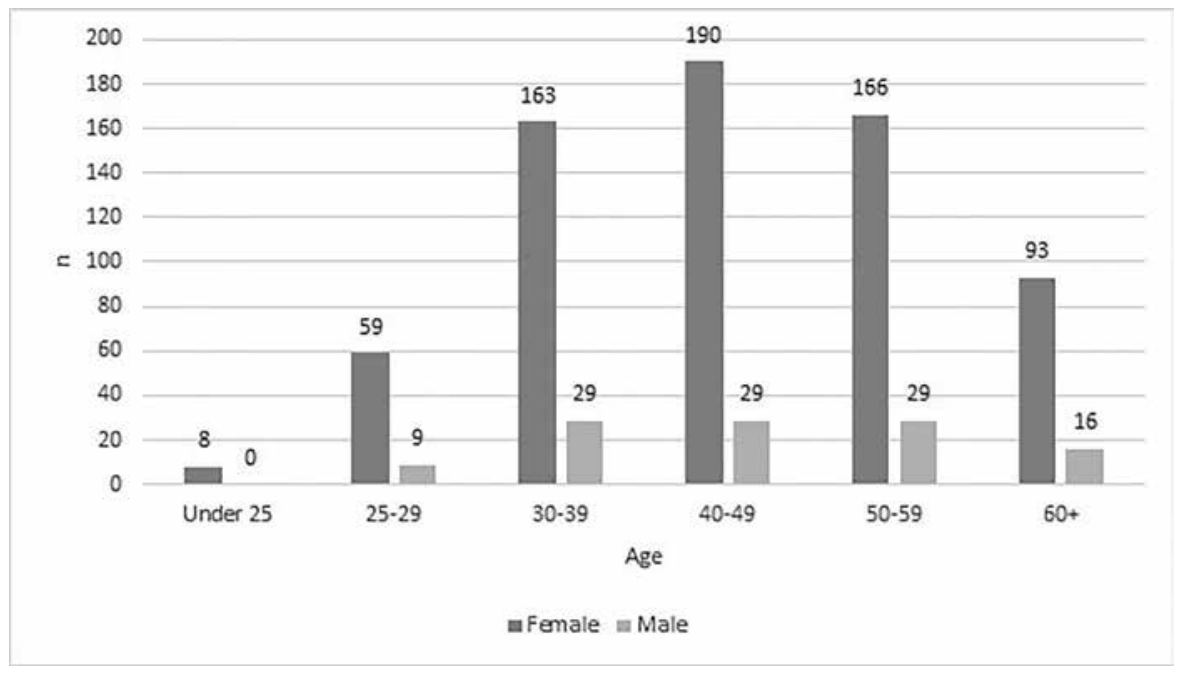

Figure 1. Gender and age of respondents.

Table 1. ECTS credits for formal education in art and crafts.

\begin{tabular}{lcc}
\hline & $\mathbf{n}$ & $\mathbf{\%}$ \\
\hline No formal education in A\&C & 123 & 15.7 \\
15 ECTS or less & 57 & 7.3 \\
$16-30$ ECTS & 105 & 13.4 \\
$31-60$ ECTS & 129 & 16.4 \\
$61-90$ ECTS & 72 & 9.2 \\
$90-120$ ECTS & 229 & 29.2 \\
More than 120 ECTS & 70 & 8.9 \\
\hline Total & 785 & $100 \%$ \\
\hline
\end{tabular}


Approximately $28 \%$ of the respondents taught only A\&C. Of these, $12 \%$ had less than 15 ECTS credits for specializing in A\&C. For nearly half the respondents, or $43 \%$, of those who also taught other subjects, less than $20 \%$ of their teaching duties consisted of A\&C.

As depicted in Table $2,42.8 \%$ of the respondents had taught for seven years or less and $33 \%$ for 16 years or more.

Table 2. Number of years in service.

\begin{tabular}{lcc}
\hline & $\mathbf{n}$ & $\mathbf{\%}$ \\
\hline Three years or less & 164 & 20.9 \\
$4-7$ years & 172 & 21.9 \\
$8-11$ years & 114 & 14.5 \\
$12-15$ years & 75 & 9.6 \\
16 years or more & 259 & 33.0 \\
\hline Total & 784 & $100 \%$ \\
\hline
\end{tabular}

\section{Results}

The overall results of the 22 statements are presented in Table 3 that shows how many respondents strongly agree or agree $\left(^{\star}\right)$, neither agree nor disagree $\left(^{\star \star}\right)$ or disagree or strongly disagree $\left({ }^{\star \star}\right)$ to each statement. Over $90 \%$ of the respondents strongly agreed or agreed on the following five statements: whether creativity could be used in all school subjects, whether it was an important skill, whether it should be emphasized in schools, and whether everyone could be creative.

Notably, opinions were very dissimilar with regard to several statements. As described earlier, one of the core definitions of creativity concerns originality. Nearly half of the respondents strongly agreed or agreed that creativity could be defined as producing something original, but $21 \%$ disagreed or strongly disagreed with this statement. Twenty-six percent strongly agreed or agreed that creativity is innate, and $27 \%$ disagreed or strongly disagreed. Even though most stated that creativity could be central in all school subjects, almost half of the respondents strongly agreed or agreed that it was easier to develop creative abilities in $\mathrm{A} \& \mathrm{C}$ than in other school subjects and only $21 \%$ disagreed with this statement.

The two statements that were linked to creativity and adult life and experience received different answers. Forty-six percent neither agreed nor disagreed on whether it takes a long time to attain the same level of creativity as significant artists and inventors, but $40 \%$ strongly agreed or agreed with this statement. However, interestingly, 93\% strongly agreed or agreed that children can develop creative ideas just as well as adults.

Two statements within the survey related to assessment. Two thirds of the respondents agreed or strongly agreed that it was possible to assess creativity and $27 \%$ neither agreed nor disagreed. Only $24 \%$ agreed or strongly agreed that the teacher is the one who assesses creativity while $21.5 \%$ disagreed or strongly disagreed with this statement. 
Table 3. The respondents' answers to the 22 statements on creativity.

\begin{tabular}{|c|c|c|c|c|c|}
\hline Statement & $\star$ & $\star \star$ & $\star \star \star$ & Total & $\mathbf{n}$ \\
\hline It is only relevant to work with creativity in art and crafts & $6 \%$ & $6 \%$ & $88 \%$ & $100 \%$ & 771 \\
\hline Creativity can be defined as producing something original & $49 \%$ & $30 \%$ & $21 \%$ & $100 \%$ & 758 \\
\hline Creativity can be used in all school subjects & $97 \%$ & $2 \%$ & $1 \%$ & $100 \%$ & 772 \\
\hline Everyone can be creative & $93 \%$ & $5 \%$ & $2 \%$ & $100 \%$ & 772 \\
\hline Creativity can be taught & $89 \%$ & $10 \%$ & $1 \%$ & $100 \%$ & 773 \\
\hline Creativity is innate & $26 \%$ & $48 \%$ & $27 \%$ & $100 \%$ & 770 \\
\hline It is possible to assess creativity & $66 \%$ & $27 \%$ & $7 \%$ & $100 \%$ & 762 \\
\hline It is easier to develop creative abilities in art and crafts than in other subjects & $44 \%$ & $35 \%$ & $21 \%$ & $100 \%$ & 775 \\
\hline The inventory in the classroom and access to materials will affect creativity & $88 \%$ & $10 \%$ & $2 \%$ & $100 \%$ & 771 \\
\hline Student collaboration is important for developing creativity & $73 \%$ & $24 \%$ & $3 \%$ & $100 \%$ & 769 \\
\hline It is important for all to learn creativity & $93 \%$ & $6 \%$ & $1 \%$ & $100 \%$ & 769 \\
\hline The teacher is the one who assesses student creativity & $24 \%$ & $55 \%$ & $21 \%$ & $100 \%$ & 764 \\
\hline Students need to learn working techniques before they can be creative & $34 \%$ & $36 \%$ & $30 \%$ & $100 \%$ & 769 \\
\hline Children can have creative ideas that are just as good as adults' & $93 \%$ & $5 \%$ & $2 \%$ & $100 \%$ & 766 \\
\hline $\begin{array}{l}\text { It is important to emphasize the student's interpretation of the experience } \\
\text { when working with creativity }\end{array}$ & $65 \%$ & $32 \%$ & $2 \%$ & $100 \%$ & 742 \\
\hline Creativity is a fundamental trait that should be emphasized in schools & $92 \%$ & $7 \%$ & $1 \%$ & $100 \%$ & 770 \\
\hline $\begin{array}{l}\text { It takes a long time to attain the same level of creativity as significant } \\
\text { artists or inventors }\end{array}$ & $40 \%$ & $46 \%$ & $14 \%$ & $100 \%$ & 759 \\
\hline Creativity is important for future working life & $96 \%$ & $4 \%$ & $0 \%$ & $100 \%$ & 770 \\
\hline $\begin{array}{l}\text { It is possible to emphasize creative processes in the classroom without } \\
\text { focusing on the final product }\end{array}$ & $89 \%$ & $9 \%$ & $2 \%$ & $100 \%$ & 768 \\
\hline $\begin{array}{l}\text { It is important for children to develop knowledge in order to become } \\
\text { more creative }\end{array}$ & $80 \%$ & $18 \%$ & $2 \%$ & $100 \%$ & 767 \\
\hline The social environment in the classroom will affect individual creativity & $86 \%$ & $13 \%$ & $1 \%$ & $100 \%$ & 771 \\
\hline Students have different needs when it comes to the development of creativity & $89 \%$ & $10 \%$ & $1 \%$ & $100 \%$ & 762 \\
\hline
\end{tabular}

${ }^{\star}$ Strongly agree or agree ${ }^{\star \star}$ Neither agree nor disagree ${ }^{\star \star \star}$ Disagree or strongly disagree

There was a significant difference between those who had specialist teacher education and those who did not with regard to three of the statements: creativity is innate, $i t$ is possible to assess creativity and the teacher is the one who assesses student creativity. Table 4 shows the difference in answers between the two groups. A smaller percentage of those who had a specialized teacher's education stated that creativity was innate. A larger percentage of those who had a specialized teacher education stated that it was possible to assess creativity, and that the teacher was the one who does so. Interestingly, however, only $30.7 \%$ of that group stated that this assessment was actually the teacher's task.

There was also a significant difference between those who had taught for seven years or less and those who had taught for more than 16 years with regard to two of the statements; it is possible to assess creativity and it takes a long time to reach the same level of 


\section{B. Olafsson}

Table 4. Comparison between those with a specialist teacher education and those without.

\begin{tabular}{|c|c|c|c|c|c|}
\hline \multicolumn{6}{|c|}{ Creativity is innate $(\mathrm{X} 2(2, \mathrm{~N}=765=6.06, \mathrm{p}=0.048))$} \\
\hline & $\star$ & $\star \star$ & $\star \star \star$ & Total & $\mathrm{N}$ \\
\hline Have specialist teacher education & $21.2 \%$ & $48.1 \%$ & $30.7 \%$ & $100 \%$ & 283 \\
\hline Do not have specialist teacher education & $27.8 \%$ & $48.1 \%$ & $24.1 \%$ & $100 \%$ & 428 \\
\hline \multicolumn{6}{|c|}{ It is possible to assess creativity $(\mathrm{X} 2(2, \mathrm{~N}=757=7.84, \mathrm{p}=0.020))$} \\
\hline & $\star$ & $\star \star$ & $\star \star \star$ & Total & $\mathrm{N}$ \\
\hline Have specialist teacher education & $69.9 \%$ & $26.2 \%$ & $3.9 \%$ & $100 \%$ & 279 \\
\hline Do not have specialist teacher education & $63.6 \%$ & $27.2 \%$ & $9.2 \%$ & $100 \%$ & 478 \\
\hline \multicolumn{6}{|c|}{ The teacher is the one who assesses student creativity $(\mathrm{X} 2(2, \mathrm{~N}=759=12.33, \mathrm{p}=0.002))$} \\
\hline & $\star$ & $\star \star$ & $\star \star \star$ & Total & $\mathrm{N}$ \\
\hline Have specialist teacher education & $30.7 \%$ & $51.4 \%$ & $17.9 \%$ & $100 \%$ & 280 \\
\hline Do not have specialist teacher education & $19.8 \%$ & $56.6 \%$ & $23.6 \%$ & $100 \%$ & 479 \\
\hline
\end{tabular}

${ }^{\star}$ Strongly agree or agree ${ }^{\star \star}$ Neither agree nor disagree ${ }^{\star \star \star}$ Disagree or strongly disagree.

creativity as significant artists or inventors. Table 5 shows the difference in answers between the two groups. Of those who had taught for 7 years or less, $57.4 \%$ stated it was possible to assess creativity, while for those who had taught 16 years or more the figure was $71.6 \%$. A larger percentage of those teachers with more experience suggested that it takes a long time to attain the same level of creativity as significant artists or inventors.

Table 5. Comparison between those with 7 years or less teaching experience in $A \& C$ and those with more than 16 years of experience.

\begin{tabular}{|c|c|c|c|c|c|}
\hline \multicolumn{6}{|c|}{ It is possible to assess creativity $(\mathrm{X} 2(2, \mathrm{~N}=557=12.31, \mathrm{p}=0.002))$} \\
\hline & * & $\star \star$ & $\star \star \star$ & Total & $\mathrm{N}$ \\
\hline 7 years or less & $57.4 \%$ & $32.7 \%$ & $10.0 \%$ & $100 \%$ & 251 \\
\hline 16 years or more & $63.6 \%$ & $27.2 \%$ & $9.2 \%$ & $100 \%$ & 306 \\
\hline \multicolumn{6}{|c|}{$\begin{array}{l}\text { It takes a long time to reach the same level of creativity as significant artists or inventors }(\mathrm{X} 2(2, \mathrm{~N}=554=20.67 \\
\mathrm{p}=0.000))\end{array}$} \\
\hline & $\star$ & $\star \star$ & $\star \star \star$ & Total & $\mathrm{N}$ \\
\hline 7 years or less & $30.8 \%$ & $48.0 \%$ & $21.2 \%$ & $100 \%$ & 250 \\
\hline 16 years or more & $46.4 \%$ & $43.8 \%$ & $9.9 \%$ & $100 \%$ & 304 \\
\hline
\end{tabular}

${ }^{\star}$ Strongly agree or agree ${ }^{\star \star}$ Neither agree nor disagree ${ }^{\star \star \star}$ Disagree or strongly disagree.

\section{Discussion}

These findings provide insights into varying aspects of the conceptions that teachers have regarding creativity. In the results of the study, three themes stand out as interesting for discussion. These are individual creative capacity, domain knowledge, and assessment. The emphasis in the discussion is on how that understanding could possibly affect creativity-fostering practices. 


\section{Individual creative capacity}

The majority of respondents agreed that creativity is important, as other studies have also revealed (e.g., Cachia \& Ferrari, 2010; Kampylis, Berki \& Saariluoma, 2009). The respondents, however, expressed various opinions on the nature of the individual's creative capacity. Approximately one-quarter disagreed that creativity is innate and one-quarter agreed with this statement. This ratio was different for both Cachia and Ferrari (2010) and Kampylis et al. (2009), where a much lower percentage believed creativity was innate. However, in Lutnæs' (2011) findings, respondents outlined creativity as an innate ability rather than something that could be learned. It is also interesting to note that only $89 \%$ of the respondents strongly agreed or agreed that creativity can be taught. Considering this figure and the answers to whether creativity is innate, one might conjecture that some respondents hold the opinion that creativity could simply be out of reach for some students, or that they find it challenging to support students who show poor creativity or motivation in A\&C. However, if one looks at the strong relationship between creativity and learning, as many scholars have pointed out (e.g., Beghetto \& Kaufman, 2007; Sawyer, 2010; Vygotsky, 1967/2004), all healthy individuals should be capable of creative thinking. This does not mean that all learning is creative, but that every individual has creative potential and can develop his creativity. Furthermore, the national curriculum (Ministry of Education and Research, 2006) outlines creativity as something that all students should learn and develop. Awareness of the relationship between creativity and learning and other creativity-fostering elements would support teachers to look beyond the actions of a person and attempt to find ways to motivate and help students develop their creativity.

Interestingly, the results of this study also reveal that smaller groups of respondents who have specialized teacher education say that creativity is innate. This could mean that teachers with specialized teacher education in A\&C find it easier to develop creativity in their students than those who do not. Perhaps this is because they have a better conception of creativity or that their own creativity and domain knowledge help them understand how they can support students. Creativity scholars have suggested a strong link between a teacher's creativity and student creativity, and even suggesting that a teacher's creativity is a premise for student creativity (NACCCE, 1999; Olafsson \& Gulliksen, 2018). Therefore, student creativity may largely be dependent on the teacher's knowledge and skill in the A\&C school subject.

\section{Domain knowledge}

This study indicates that many of the respondents view creativity as getting an idea and being domain-general. Despite the majority saying that creativity can be used in all school subjects, almost half of the respondents stated that it was easier to develop creativity within A\&C. As noted earlier, creativity has often been linked to the arts (e.g., Kampylis et al., 2009). It is not surprising that A\&C teachers, who value their school subject, have this opinion. Furthermore, 93\% stated that children could have ideas that are just as creative as those of adults. This indicates that the majority 


\section{B. Olafsson}

of the respondents perceive creativity as forming an idea and undermining the role of domain knowledge for new and novel ideas. Furthermore, this indicates a lack of focus on the sociocultural (contributing with something of significance to a domain).

Domain-specific or domain-general emphasis will lead to various approaches to teaching and different learning outcomes. If a teacher seeks to focus on domainspecific excellence, he should focus on task-specific instruction (Baer, 1998). On the other hand, if the focus is on domain generality, the teacher should introduce students to a variety of materials and techniques, and expose them to a wide area of contexts in which those can be applied in a creative way (Barab \& Plucker, 2002). The current A\&C curriculum (Ministry of Education and Research, 2006) emphasizes the latter, as it requires the teacher to introduce students to varieties of materials and techniques. In fact, it could be argued that it connects to several domains with emphasis on art, design, and vocational education.

However, creativity scholars have pointed out that extensive domain knowledge is important to make a groundbreaking contribution to a domain (e.g., Csikszentmihalyi, 1999; Gardner, 1993; Sawyer, 2013). Consequently, focusing on domain knowledge and creativity as domain-specific will, in theory, support students to greater creative achievements later in life. Indeed, $80 \%$ of the respondents in this research stated that it is important for children to develop knowledge to become more creative. That seems logical, or to take an example: Without knowledge of the attributes of wood and the appropriate tools to process it, it is difficult to make a wooden toy in a creative way in A\&C. Nevertheless, controversially, only $40 \%$ of the respondents agreed that attaining the same level of creativity as significant artists or inventors takes a long time. Again, this indicates that many of the respondents look at creativity as getting an idea rather than something that is a result of extensive knowledge and experience. However, the results reveal that teachers' views in this regard change somewhat as their level of experience increases (see Table 5), which indicates that a better understanding of the importance of domain knowledge for creativity comes with more experience.

Deeper conceptual understanding of a domain will also support flexibility and the transfer of knowledge to new situations (Sawyer, 2014). This requires deep learning; going deeper into certain aspects of the curriculum and certain core elements within a domain as well as task-specific instruction. Deep learning will support the generation of new ideas, creative flexibility, transfer, and domain knowledge that could lead to eminent creativity. Deep learning is a main emphasis in the new Norwegian national curriculum for compulsory education, Fagfornyelsen, which will be implemented in 2020 (Gilje, Landvald \& Ludvigsen, 2018; UDIR, 2019a). One of the aims for the new curriculum is to reduce the number of learning goals to enable teachers to meet the goal for deep learning. However, the latest draft of the new $\mathrm{A} \& \mathrm{C}$ curriculum for compulsory education still requires the teacher to cover a wide range of materials, techniques, and theory (UDIR, 2019b) that could be a hindrance for deep learning. 


\section{Assessment}

There are no guidelines for assessment of students' creativity in the Norwegian A\&C curriculum. However, the curriculum requires teachers to give students grades when they finish studies of the $\mathrm{A} \& \mathrm{C}$ subject in compulsory education. Nevertheless, it was not clear to the respondents how to assess creativity, as only $66 \%$ of the respondents agreed or strongly agreed that it was possible to assess creativity and $7 \%$ disagreed or strongly disagreed with this statement. This supports Lutnæs' (2011) findings relating to how teachers struggled to define originality and personal expression and found it easier to assess the technical aspects of student products. Assessment has been a weakness in $\mathrm{A} \& \mathrm{C}$ education in Norway, and no clear criteria for how to assess creativity currently exist (Bamford, 2012; Lutnæs, 2013, 2018). Norwegian A\&C teachers have developed several tools, such as portfolios and rubrics, to assess students' achievements (e.g., Lutnæs, 2009; Lutnæs 2018; Moe, 2012; Øidvin, 2010), but it is difficult to capture the complexity of students' creative achievements or provide teachers the confidence they need. The fact that there are more complaints about final grades in $\mathrm{A} \& \mathrm{C}$ and other practical school subjects in compulsory education (Skolt, 2014) is another indication that assessment in A\&C is unclear and complicated.

Assessment of creativity in any domain is complicated, and a good model is yet to be developed (Hennessey, 2017). However, Beghetto (2005) points out that assessment during creative activities in a classroom is fundamental to the development of students' creativity. Consequently, continuous assessment and feedback might be vital for the progress of students' work. Adequate knowledge and experience in A\&C is needed to develop domain-specific practices for continuous assessment. Following a domain-general guideline for assessment may potentially reduce creativity to a mechanical process that does not take into account how creativity unfolds in $\mathrm{A} \& \mathrm{C}$. Additionally, teachers' conceptual understanding of creativity can affect the way they perceive assessment. For example, previous research has indicated that those who believe creativity can be assessed understand creativity as a skill, while others look at creativity as innate, and therefore something that could not be acquired (Rogers $\&$ Fasciato, 2005).

A larger percentage of those who have specialized teacher education in A\&C agreed that it is possible to assess creativity, as depicted in Table 4 . Moreover, only $24 \%$ strongly agreed or agreed that the teacher was the one to assess student creativity. Again, a larger percentage of those with specialized A\&C teacher education agreed with this statement compared to those with no such specialization (see Table 4). Consequently, those with specialized $A \& C$ teacher education are more confident in assessing creativity.

\section{Conclusion}

The aim of this study was to gain knowledge on how A\&C teachers in Norwegian compulsory education comprehend creativity. The results confirm recent findings 
that teachers' ideas are in misalignment with current literature. In this research, this misalignment became especially evident regarding individual creative capacity and domain knowledge. The results indicate that some $\mathrm{A} \& \mathrm{C}$ teachers hold the opinion that creativity cannot be developed in all students, and that they find it challenging to support students showing poor creativity skills or a lack of motivation. Furthermore, the results indicate that most $A \& C$ teachers view creativity mainly as domain general. As a result, they focus less on domain knowledge that underpins possible prominent socio-cultural creative accomplishments later in life. This understanding can influence how teachers approach deep learning and transfer of knowledge, as emphasized in the new national curriculum for compulsory education that will be implemented in 2020 (UDIR, 2019a; UDIR, 2019b). Emphasizing domain knowledge, deep learning and transfer in creative work will require a different approach in teaching than focusing on creativity as a domain general trait. Results indicate, furthermore, that $\mathrm{A} \& \mathrm{C}$ teachers find it challenging to assess creativity. This substantiates the findings of Bamford (2012), calling for an improvement of the criteria and directions on assessment in $\mathrm{A} \& \mathrm{C}$ education in Norway.

The results presented here do not suggest that $A \& C$ teachers lack techniques or practices to encourage students' creativity, development or expressions. Rather, they indicate that $\mathrm{A} \& \mathrm{C}$ teachers may build on their positive attitudes and facilitate better creative practices by improving their conceptual understanding. The following recommendations can be made on the basis of this study. First, the results should encourage in service $\mathrm{A} \& \mathrm{C}$ teachers to acquire and implement new research-based knowledge on creativity in education. A forum for sharing theoretical- and researchbased ideas for teaching would support their understanding and teaching practices. Second, A\&C teacher education needs to implement a deeper conceptual understanding of creativity. According to Beghetto (2017) teaching about creativity will support the creativity of students through an awareness and understanding of different personal and socio-cultural creativity manifestations. Third, the results suggest that legislators need to apply evidence-based knowledge and definitions when establishing creativity as a significant learning outcome in the national curriculum, in order to support teachers practice and understanding. Fourth, in order to meet the goals of individual creativity development and assessment in the curriculum, improved guidelines are needed. The new A\&C curriculum draft encourages deep learning and creativity (UDIR, 2019b), yet it is not evident how this might be realized in practice.

Finally, the findings in this article show the need for additional research in order to identify how $A \& C$ teachers aqcuire their conceptions of creativity - and how these conceptions in turn influence their teaching practices.

\section{Author biography}

Brynjar Olafsson is an assistant professor in art and crafts education at the Department of Visual and Performing Arts Education, University of South-Eastern Norway. 
He is currently the president of NordFo, Nordic Forum for Research and Development in Educational Sloyd. He has been an editor for the national compulsory curriculum for crafts in Iceland, and has published several articles and book chapters on topics related to art and crafts education.

\section{References}

Al-Nouh, N. A., Abdul-Kareem, M. M. \& Taqi, H. A. (2014). Primary school EFL teachers' attitudes towards creativity and their perceptions of practice. English Language Teaching, 7(9), 74-90. http://dx.doi.org' 10.5539/elt.v7n9p74

Amabile, T. M. (1982). Social psychology of creativity: A consensual assessment technique. Fournal of Personality and Social Psychology, 43(5), 997-1013. https://doi.org/10.1037/0022-3514.43.5.997

Amabile, T. M. (1996). Creativity in Context. Boulder, CO: Westview Press.

Baer, J. (1998). The case for domain specificity of creativity. Creativity Research fournal, 11(2), 173-177. https:// doi.org/10.1207/s15326934crj1102_7

Baer, J. (2012). Domain specificity and the limits of creativity theory. The fournal of Creative Behavior, 46(1), 16-29. https://doi.org/10.1002/jocb.002

Baer, J. (2019). Theory in Creativity Research: The Pernicious Impact of Domain Generality. In C. A. Mullen (Ed.), Creativity Under Duress in Education? (CTAE, vol. 3, pp. 119-135). Cham: Springer. https://doi. org/10.1007/978-3-319-90272-2

Bamford, A. (2012). Arts and cultural education in Norway 2010/2011 (Report, The Norwegian Centre for Arts and Cultural Education). Retrieved from https://kunstkultursenteret.no/wp-content/uploads/2019/01/ Arts-and-Cultural-Education-in-Norway-2010-2011.pdf

Barab, S. \& Plucker, J. (2002). Smart people or smart contexts? Cognition, ability, and talent development in an age of situated approaches to knowing and learning. Educational Psychologist, 37(3). 165-182. https://doi. org/ 10.1207/S15326985EP3703_3

Beghetto, R. A. (2005). Does assessment kill student creativity? The Educational Forum, 69(3), 254-263. https:// doi.org/10.1080/00131720508984694

Beghetto, R. A. (2013). Killing ideas softly. The promise and perils of creativity in the classroom. Charlotte, NC: Information Age Publishing.

Beghetto, R. A. (2017). Creativity in Teaching. In J. Kaufman, V. Glăveanu \& J. Baer (Eds.), Cambridge Handbook of Creativity across Different Domains (pp. 549-564). Cambridge: Cambridge University Press.

Beghetto, R.A. \& Kaufman, J. C. (2007). Toward a broader conception of creativity: A case for "mini-c" creativity. Psychology of Aesthetics, Creativity, and the Arts, 1(2), 73-79. https://doi.org/10.1037/1931-3896.1.2.73

Beghetto, R. A. \& Kaufman, J. C. (2010). Broadening Conceptions of Creativity in the Classroom. In R. Beghetto \& J. Kaufman (Eds.), Nurturing Creativity in the Classroom (pp. 191-205). Cambridge: Cambridge University Press. https://doi.org/10.1017/CBO9780511781629.010

Beghetto, R. A. \& Kaufman, J. C. (Eds.). (2017). Nurturing Creativity in the Classroom (2 ${ }^{\text {nd }}$ ed.). Cambridge: Cambridge University Press. https://doi.org/10.1017/CBO9780511781629

Bereczki, E. O. \& Kárpáti, A. (2018). Teachers' beliefs about creativity and its nurture: A systematic review of the recent research literature. Educational Research Review, 23, 25-56. https://doi.org/10.1016/j.edurev. 2017.10.003

Bolden, D. S., Harries, T. V. \& Newton, D. P. (2010). Pre-Service Primary Teachers' Conceptions of Creativity in Mathematics. Educational Studies in Mathematics, 73(2), 143-157. https://doi.org/10.1007/s10649-0099207-z

Cachia, R. \& Ferrari, A. (2010). Creativity in Schools: A Survey of Teachers in Europe (Report, European Commission). Retrieved from http://publications.jrc.ec.europa.eu/repository/bitstream/JRC59232/jrc 59232.pdf

Colman, A. M. (2008). Oxford Dictionary of Psychology. Oxford: Oxford University Press.

Craft, A. (2000). Creativity Across the Primary Curriculum: Framing and Developing Practice. Abingdon, UK: Routledge.

Craft, A. (2011). Creativity and Education Futures: Learning in a Digital Age. Stoke-on-Trent: Trentham Books.

Csikszentmihalyi, M. (1999). Implications of a Systems Perspective for the Study of Creativity. In R. J. Sternberg (Ed.), Handbook of Creativity (pp. 313-335). Cambridge: Cambridge University Press. https:// doi.org/10.1017/CBO9780511807916.018 


\section{B. Olafsson}

Davies, D., Jindal-Snape, D., Collier, C., Digby, R., Hay, P. \& Howe, A. (2013). Creative learning environments in education - A systematic literature review. Thinking Skills and Creativity, 8, 80-91. https://doi. org/10.1016/j.tsc. 2012.07.004

Diakidoy, I. N. \& Kanari, E. (1998). Student Teachers' Beliefs about Creativity. British Educational Research fournal, 25(2), 225-243. https://doi.org/10.1080/0141192990250206

Eckhoff, A. (2011). Creativity in the Early Childhood Classroom: Perspectives of Preservice Teachers. Fournal of Early Childhood Teacher Education, 32(3), 240-255. https://doi.org/10.1080/10901027.2011.594486

Espeland, M., Arnesen, T. E., Grønsdal, I. A., Holthe, A., Sømoe, K., Wergedahl, H. \& Aadland, H. (2013). Skolefagsundersøkelsen 2011: Praktiske og estetiske fag på barnesteget i norsk grunnskule (HSH-rapport 2013/7). Retrieved from http://hdl.handle.net/11250/152148

Fryer, M. \& Collings, J. A. (1991). Teachers' views about creativity. British fournal of Educational Psychology, 61(2), 207-219. https://doi.org/10.1111/j.2044-8279.1991.tb00976.x

Gardner, H. (1993). Creating Minds. New York: Basic Books.

Gilje, Ø., Landvald, Ø. F. \& Ludvigsen, S. (2018). Dybdelæring - historisk bakgrunn og teoretiske tilnærminger. Bedre skole, 30(4), 22-27. Retrieved from https://www.utdanningsnytt.no/files/2019/06/27/Bedre $\% 20$ Skole $\% 204 \% 202018 . p d f$

Gjærum, R. G. \& Gran, A. (2016, September 29). Grunnskolen dreper kreativiteten. Nordlys. Retrieved from https:/www.bi.no/globalassets/forskning/institutt-for-kommunikasjon-og-kultur/media/2016-09-29_ grunnskolen-dreper-kreativiteten.pdf

Helfand, M., Kaufman, J. C. \& Beghetto R. A. (2016) The Four-C Model of Creativity: Culture and Context. In V. Glăveanu (Eds.), The Palgrave Handbook of Creativity and Culture Research. Palgrave Studies in Creativity and Culture (pp. 15-36). London: Palgrave Macmillan. https://doi.org/10.1057/978-1-137-46344-9_2

Hennessey, B. (2017). Intrinsic motivation and creativity in the classroom. In R. Beghetto \& J. Kaufman (Eds.), Nurturing creativity in the classroom ( $2^{\text {nd }}$ ed.) (pp. 227-264). Cambridge: Cambridge University Press. https://doi.org/10.1017/CBO9780511781629.017

Kampylis, P., Berki, E. \& Saariluoma, P. (2009). In-service and prospective teachers' conceptions of creativity. Thinking Skills and Creativity, 4(1), 15-29. https://doi.org/10.1016/j.tsc.2008.10.001

Kaufman, J. C. (2016). Creativity 101 (2nd ed.). New York: Springer Publishing Company.

Kaufman, J. C. \& Beghetto, R. A. (2009). Beyond Big and Little: The Four C Model of Creativity. Review of General Psychology, 13(1), 1-12. https://doi.org/10.1037/a0013688

Kim, K. H. (2011). The Creativity Crisis: The Decrease in Creative Thinking Scores on the Torrance Tests of Creative Thinking. Creativity Research fournal, 23(4), 285-295. https://doi.org/10.1080/10400419.2011.6 27805

Lev-Zamir, H. \& Leikin, R. (2011). Creative mathematics teaching in the eye of the beholder: focusing on teachers' conceptions. Research in Mathematics Education, 13(1), 17-32. https://doi.org/10.1080/1479480 2.2011 .550715

Lutnæs, E. (2009). Vurdering i kunst og håndverk. Form, (43)2, 4-6. Retrieved from https://www.formbanken. no/form-2/2018/3/10/vurdering-i-kunst-og-hndverk

Lutnæs, E. (2011). Standpunktvurdering $i$ grunnskolefaget Kunst og håndverk - lcereres forhandlingsrepertoar (Doctoral dissertation, The Oslo School of Architecture and Design, Norway). Retrieved from https://aho. brage.unit.no/aho-xmlui/bitstream/handle/11250/93051/lutnaes.pdf?sequence $=3$ \&isAllowed $=\mathrm{y}$

Lutnæs, E. (2013).Vurdering av kreativitet i grunnskolefaget Kunst og håndverk - et svakt ledd? Form, 47(4), 8-10. Retrieved from https:/www.formbanken.no/form-2/2018/5/2/vurdering-av-kreativitet-i-grunnskolefagetkunst-og-hndverk-et-svakt-ledd

Lutnæs, E. (2018). Creativity in assessment rubrics. Paper presented at the International conference on engineering and product design education, Dyson school of design engineering, Imperial College, London, UK. Abstract retrieved from https://www.designsociety.org/publication/40842/CREATIVITY+IN+ ASSESSMENT+RUBRICS

Ministry of Education and Research. (2006). Kunnskapsløftet. Oslo: Kunnskapsdepartementet.

Moe, E. (2012). Estetiske vurderinger i faget kunst og håndverk. Form, 46(3), 16-19.

Moran, S. \& John-Steiner, V. (2003). Creativity in the making: Vygotskys Contemporary Contribution to the Dialectic of Development and Creativity. In M. Marschark (Ed.), Creativity and Development (pp. 61-90). Oxford: Oxford University Press. https://doi.org/10.1093/acprof:oso/9780195149005.003.0003

Mullet, D. R., Willerson, A., Lamb, K. N. \& Kettler, T. (2016). Examining teacher perceptions of creativity: A systematic review of the literature. Thinking Skills and Creativity, 21, 9-30. https://doi.org/10.1016/j. tsc. 2016.05 .001 


\section{Norwegian art and crafts teachers' conceptions of creativity}

National Advisory Committee on Creative and Cultural Education. (1999). All Our Futures: Creativity, Culture and Education (NACCCE Report). Retrieved from http://sirkenrobinson.com/pdf/allourfutures.pdf

National Research Council. (2000). How People Learn: Brain, Mind, Experience, and School (Exp. ed.). Washington, D.C: National Academy Press. Retrieved from https://www.nap.edu/read/9853/chapter/1

Newton, L. D. (Ed.). (2012). Creativity for a new curriculum: 5-11. Abingdon, UK: Routledge.

Newton, L. \& Beverton, S. (2012). Pre-service teachers' conceptions of creativity in elementary school English. Thinking Skills and Creativity, 7(3), 165-176. https://doi.org/10.1016/j.tsc.2012.02.002

Newton, L. D. \& Newton, D. P. (2010). What Teachers See as Creative Incidents in Elementary Science Lessons. International fournal of Science Education, 32(15), 1989-2005. https://doi.org/10.1080/09500690903233249

Olafsson, B. \& Gulliksen, M. S. (2018). Kreativitet i begynneropplæringen. In E. Michaelsen \& K. Palm (Eds.), Den viktige begynneropplaringen (pp. 249-266). Oslo: Universitetsforlaget.

Oskarsdottir, G., Olafsdottir, K. A., Olafsson, B., Gudmundsdottir, H. R., Kaldalons, I., Juniusdottir, R., ... Gudmundsdottir, S. (2014). List- og verkgreinar. In G. Oskarsdottir (Ed.), Starfshaettir i grunnskolum vid upphaf 21. aldarinnar (pp. 241-275). Reykjavik: Haskolautgafan.

Pajares, M. F. (1992). Teachers' Beliefs and Educational Research: Cleaning up a Messy Construct. Review of Educational Research, 62(3), 307-322. https://doi.org/10.3102/00346543062003307

Pellegrino, J. W. \& Hilton, M. L. (2013). Education for Life and Work: Developing Transferable Knowledge and Skills in the 21st Century (Report, National Research Council). Washington: National Academic Press. Retrieved from https://www.nap.edu/read/13398/chapter/1

Plucker, J. A. \& Beghetto, R. A. (2004). Why creativity is domain general, why it looks domain specific, and why the distinction does not matter. In R. J. Sternberg, E. L. Grigorenko \& J. L. Singer (Eds.), Creativity: From potential to realization (pp. 153-167). Washington: American Psychological Association.

Renzulli, J. (2017). Developing Creativity Across All Areas of the Curriculum. In R. A. Beghetto \& J. C. Kaufman (Eds.), Nurturing creativity in the classroom (2 ${ }^{\text {nd }}$ ed.) (pp. 23-44). New York: Cambridge University Press. https://doi.org/10.1017/9781316212899.006

Rogers, M. \& Fasciato, M. (2005). Can creativity be assessed? Paper presented at the British Educational Research Association Annual Conference. Wales: University of Glamorgan. Retrieved from http://www.leeds.ac.uk/ educol/documents/150029.htm

Runco, M. A. \& Jaeger, G. J. (2012). The Standard Definition of Creativity. Creativity Research fournal, 24(1), 92-96. https://doi.org/10.1080/10400419.2012.650092

Sawyer, R. K. (2010). Learning for Creativity. In R. A. Beghetto \& J. C. Kaufman (Eds.), Nurturing creativity in the classroom (pp. 172-190). Cambridge: Cambridge University Press.

Sawyer, R. K. (2012). Explaining Creativity. The Science of Human Innovation. Oxford: Oxford University Press.

Sawyer, R. K. (2013). Zig Zag: The Surprising Path to Greater Creativity. San Fransisco, CA: Jossey Bass.

Sawyer, R. K. (2014). Introduction. The New Science of Learning. In R. K. Sawyer (Ed.), The Cambridge Handbook of the Learning Sciences (2nd ed., pp. 1-18). Cambridge: Cambridge University Press.

Skolt, H. (2014, July 31). Klagene synker drastisk. Moss Avis. Retrieved from https://www.moss-avis.no/nyheter/ klagene-synker-drastisk/s/2-2.2643-1.8528124

Sternberg, R. J. (2009). Domain-Generality Versus Domain-Specificity of Creativity. In P. Meusburger, J. Funke \& E. Wunder (Eds.), Milieus of Creativity: An Interdisciplinary Approach to Spatiality of Creativity (pp. 25-38). Dordrecht: Springer. https://doi.org/10.1007/978-1-4020-9877-2_3

Svare, H. (2014). User-Producer Dialogue, Workplace Innovation, and Knowledge in a Regional Innovation System. Fournal of the Knowledge Economy, 7(2), 565-586. https://doi.org/10.1007/s13132-014-0229-0

Utdanningsdirektoratet. (2019a). Fagfornyelsen. Retrieved from https://www.udir.no/laring-og-trivsel/ lareplanverket/fagfornyelsen/

Utdanningsdirektoratet. (2019b). Høring - læreplaner i kunst og håndverk og duodji (2019/3831). Retrieved from https://hoering.udir.no/Hoering/v2/341

Vygotsky, L. S. (1967/2004). Imagination and Creativity in Childhood. Fournal of Russian and East European Psychology, 42(1), 7-97. https://doi.org/10.1080/10610405.2004.11059210

Winner, E., Goldstein, T. \& Vincent-Lancrin, S. (2003). Art for Art's Sake? The Impact of Arts Education (Report, Educational Reseach and Innovation). Paris: OECD Publishing. https://dx.doi.org/10.1787/ 9789264180789-en

Zbainos, D. \& Anastasopoulou, A. (2012). Creativity in Greek Music Curricula and Pedagogy: An Investigation of Greek Music Teachers' Perceptions. Creative Education, 3(1), 55-60. http://dx.doi.org/10.4236/ ce. 2012.31009

Øidvin, R. (2010). Vurderingsskjema. Form 44(1), 26-27. 


\section{B. Olafsson}

\section{Appendix 1}

\section{The 22 statements and how they relate to themes}

\section{Statement}

It is only relevant to work with creativity in art and crafts

Creativity can be defined as producing something original

Creativity can be used in all school subjects

Everyone can be creative

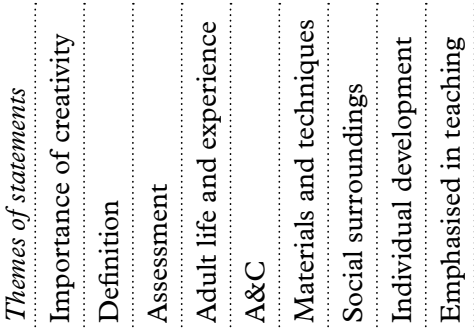

Creativity can be taught

Creativity is innate

It is possible to assess creativity

It is easier to develop creative abilities in art and crafts than other subjects

The inventory in the classroom and access to materials will affect creativity

Student collaboration is important for developing creativity

It is important for all to learn creativity

The teacher is the one who assesses student creativity

Students need to learn working techniques before they can be creative

Children can have creative ideas that are just as good as adults,

It is important to emphasise the student's interpretation of the experience when working with creativity

Creativity is a fundamental trait that should be emphasised in schools

It takes a long time to attain the same level of creativity as significant artists or inventors

Creativity is important for future working life

It is possible to emphasise creative processes in the classroom without focusing on the final product

It is important for children to develop knowledge in order to become more creative

The social environment in the classroom will affect individual creativity

Students have different needs when it comes to the development of creativity

$\mathrm{x}$

$\mathrm{x}$

\section{$\mathrm{X}$}

$\mathrm{X}$

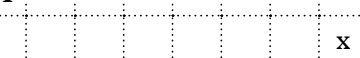

$\mathrm{x}$

$\mathrm{x}$

$\mathrm{x}$ $\mathrm{x}$

$\mathrm{X}$

$\mathrm{x}$

$\mathrm{x}$

$\mathrm{x}$

$\mathrm{X}$

$\mathrm{x}$

$\mathrm{X}$ 